\title{
市販の日本産とアメリカ産ブロッコリーの雄性不稔の解析
}

\author{
山㟝聖司・藤㟝千華子 \\ 福岡教育大学教育学部 811-4192 福岡県宗像市赤間文教町 1-1
}

\section{Analysis of Male Sterility in Broccoli Commercially Grown in Japan and the USA}

\author{
Seiji YAMASAKI and Chikako FUJISAKI \\ Faculty of Education, Fukuoka University of Education, 1-1 Akamabunkyomachi, \\ Munakata, Fukuoka 811-4192, Japan
}

\begin{abstract}
In a laboratory experiment conducted at the author's university in August 2012, all students found large pollen grains in flower buds of broccoli (Brassica oleracea L.) commercially grown in Japan, whereas no student found pollen grains in flower buds of broccoli commercially grown in the USA. We analyzed the extent of male sterility in broccoli commercially grown in Japan and USA from April 2013 to March 2014. We classified flower buds into the following six types: stamens develop well and pollen grains are large (type A); stamens develop well but pollen grains are not large (type B); stamens are thin and pollen grains are not large (type C); stamens are flattened and pollen grains are not large (type D); stamens are flattened and partially feminized, and pollen grains are not large (type E); and stamens are flattened, partially feminized, and conjugated with stamens or pistil, and pollen grains are not large (type F). Because flower buds classified as type $\mathrm{B}$ and $\mathrm{C}$, or type $\mathrm{D}, \mathrm{E}$, and $\mathrm{F}$, coexisted in the same individual, male-sterile individuals could be grouped into $\mathrm{BC}$ or DEF individuals. Flower buds of all individuals grown in Japan were classified as type A, irrespective of locality and season. Thus, the percentage of male-sterile individuals grown in Japan was $0 \%$. In USA-grown broccoli, the percentage of type A individuals was $24.1 \%$, that of $\mathrm{BC}$ individuals was $22.0 \%$, and that of DEF individuals was $53.9 \%$. Thus, the percentage of male-sterile individuals grown in the USA was $75.9 \%$. Treatment of type A broccoli at $25{ }^{\circ} \mathrm{C}$ for 6 days indicated that flower buds of type B-F were not induced by postharvest high temperature. Using a test strip for lateral-flow type immunochromatography, flower buds of type B-F were not caused by a male sterility gene that was introduced along with the glufosinate resistance gene. It is possible that male-sterile individuals such as BC or $\mathrm{DEF}$, which are found in broccoli commercially grown in the USA, are produced by breeding.
\end{abstract}

Keywords: broccoli, male sterility, pollen grains, stamen

2014 年 4 月 9 日受付

2014 年 6 月 10 日受理

Corresponding author: Seiji Yamasaki (yamasaki@fukuoka-edu.ac.jp)

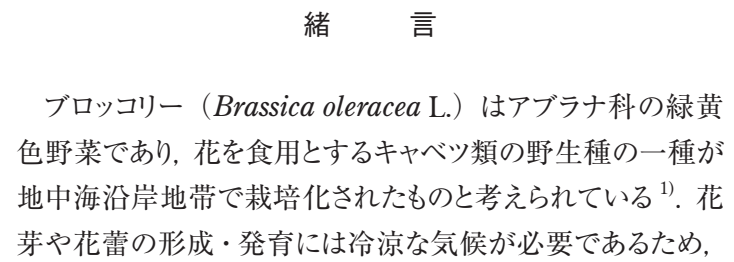


日本産ブロッコリーは, 春, 秋, 冬を中心に店頭に並ぶ. 夏の 暑い時期に店頭に並ぶ日本産ブロッコリーの産地は主に北海 道であり, 価格は高騰する. そして, 夏の暑い時期を中心 に, 安価なアメリカ産ブロッコリーが店頭に並ぶ. 店頭価格を 比較すると, 日本産に比べてアメリカ産ブロッコリーの方が 3-4 割安い傾向にある. 同じスーパーでも夏を中心に日本産と アメリカ産ブロッコリーが同時に店頭に並ぶこともあり，多様な 消費者ニーズに対応している.このように, 日本ではブロッコリ 一はスーパーで一年中入手可能な野菜の一つとして定着して いる.

ブロッコリーや小学校・中学校の教科書に掲載されている 菜の花などのアブラナ科の花は, がく片 4 枚, 花弁 4 枚, 雄 しべ 6 本, 雌しべ 1 本からなる. そのため, ブロッコリーの蕾 は教育現場において花のつくりの学習に利用できる. また, ブ ロッコリーの蕾は四分子期や一核期などの花粉の観察, がく 片に存在する気孔や維管束の観察, DNA の抽出実験などに も利用できる.このように, ブロッコリーは植物の形態, 組織, 細胞, DNAを総合的に学習できる生物教材として有用であ

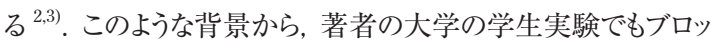
コリーを使用した前述の観察・実験を実施している. 2012 年 8 月に実施した大学の学生実験でブロッコリーの花粉の観察 を試みた際，誰も花粉を見つけられなかった，そのブロッコリ 一はアメリカ産であった. たまたま用意していた日本産ブロッコ リーを用いて同様の観察を試みた結果, 全員充実花粉を見 つけられた.これをきっかけに, 2013 年 4 月から 2014 年 3 月 まで市販の日本産とアメリカ産ブロッコリーにおいて雄性不稔 の程度と割合を解析した，その結果，雄しべの形態や花粉量 に基づき, 蕾を A-F の6タイプに分類できた. 得られた結果 をもとに, 雄性不稔の原因について考察を行った.

\section{材料および方法}

\section{1. 実験材料}

2013 年 4 月から 2014 年 3 月まで 1 か月に数回の割合で 福岡県宗像市内とその周辺の大手スーパー 6 社を回り, 日本 産ブロッコリー（Brassica oleracea L.）を合計 54 個, アメリ カ産ブロッコリーを合計 91 個購入した. 日本産ブロッコリーの 産地は, 北海道, 長崎県, 佐賀県, 福岡県であった. いずれ のスーパーでも季節や日によって日本産とアメリカ産ブロッコリ 一の取扱量は変動したが, 大手スーパー 6 社の野菜売り場 を探索することで, 安定して日本産とアメリカ産ブロッコリーを 入手できた.

\section{2. 生殖器官の形態と花粉の観察}

ブロッコリーの生殖器官の形態を解析するために, ピンセッ 卜を用いてなるべく大きな蕾（蕾長 5-7 mm）を摘み取り, 実
体顕微鏡の下で柄付き針とピンセットを用いて解剖し，がく片 と花弁を除去した後, 雄しべと雌しべの形態の観察を行っ た.この作業はブロッコリー 1 個体につき 10 個の蕾について 行った.

稔性花粉検出の簡便法としてヨード・ヨードカリ夜（ルゴー 儿液）による染色法がある ${ }^{4)}$. そこで, 前述の雄しべと雌しべ の形態の観察後, ピンセットを用いて雄しべのみを切り出し, ス ライドガラス中央に集めた後, ルゴール液 $[0.67 \%$ (w/v) ヨウ 化カリウム, $0.33 \%$ (w/v) ヨウ素]を1-2 滴落として染色し た. 3 分後, カバーガラスをかぶせ, 光学顕微鏡を用いて雄 しべ全体の観察を行った，その後，柄付き針の柄を用いてカ バーガラスの上から軽くたたき葯室を破裂させた後, 光学顕 微鏡を用いて花粉の観察を行った。

\section{3. 収穫後の高温処理が生殖器官に及ぼす影響}

アメリカ産ブロッコリーの雄性不稔が収穫後の高温条件によ り誘導された可能性を検討するために, 日本産ブロッコリーを

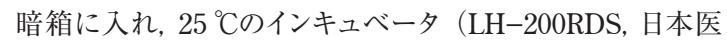
科器械製作所）の中に静置した. 2，4，6 日後にインキュベー 夕から取り出し, ブロッコリーの外観を観察した後, 「2. 生殖 器官の形態と花粉の観察」と同様の方法により, 雄しべと雌 しべの形態と花粉の観察を行った.

4. 試験紙を用いたラテラルフローイムノクロマト法による除草 剂耐性タンパク質の検出

2013 年 10 月末現在, 日本国内で販売や輸入が認められ ている遺伝子組換え作物は, トウモロコシ (Zea mays L.), ダ イズ (Glycine max), セイヨウナタネ (Brassica napus L.)，ワ 夕 (Gossypium spp.), アルファルファ (Medicago sativa L.), テンサイ (Beta vulgaris ssp. vulgaris)，ジャガイモ (Solanum tuberosum L.), パパイヤ (Carica papaya) の 8 作物 283 品種であり, 表示が義務付けられている（「遺伝子 組換元農作物」について, http://www.s.affrc.go.jp/docs/ anzenka/information/pdf/gmsakumotsu2013_11.pdf, 2014 年 5 月 28 日参照). 主な導入形質はウイルス耐性, 害 虫耐性, 除草剤耐性である。このうち, 除草剂グルホシネート (商品名: バスタ ${ }^{\circledR}$ ) 耐性を導入したセイヨウナタネには雄性 不稳遺伝子や稔性回復遺伝子も同時に組み达まれる事例が ある（カルタヘナ法に基づき第一種使用規程を承認した遺伝 子組換光農作物一覧作物別, 特性等別 平成 26 年 4 月 30 日現在, http://www.maff.go.jp/j/syouan/nouan/carta/c list/pdf/list03_20140430.pdf, 2014 年 5 月28日参照).ま た，セイヨウナタネとブロッコリーは同じ Brassica 属である. そ こで, 本研究で認められたアメリカ産ブロッコリーの雄性不稔 がグルホシネート耐性遺伝子に伴い導入された雄性不稔遺 伝子に起因する可能性を検討した. また，雄性不秎遺伝子 を, 除草剤グリホサート (商品名:ラウンドアップ・レディー ${ }^{\circledR}$ ) 
耐性遺伝子とともに導入した事例は知られていないが, グリホ サート耐性遺伝子の導入の有無も合わせて検討した。すなわ ち, グルホシネート耐性遺伝子の導入の有無には＜TRAIT > コーンバルクテストLL（1426M，アヅマックス）の試験紙を, グリホサート耐性遺伝子の導入の有無にはアグリ・スクリーン CP4（8005, Neogen）の試験紙を用いて, ラテラルフローイ ムノクロマト法により解析した.

\section{結果}

1. 生殖器官と花粉に基づく蕾のタイプ分け

市販の日本産ブロッコリー（Fig. 1A）とアメリカ産ブロッコリ

一（Fig. 1B）では外見上明確な違いは認められなかった.
しかし, 生殖器官の形態と花粉の観察の結果, 蕾を 6 タイプ に分類できた. 以下，各タイプの概要を説明する.

1 つ目は, 雄しべは十分に発達し, 花粉が充実している夕イ プである. すなわち, 雄しべについては, 数は 6 本で（Fig. 2A), 大きさや形は正常である (Fig. 2A, 2B). 花粉につい ては, 形は正常で, 葯室の破裂により放出される量が多い (Fig. 2C). これをタイプ Aと定義した.

2 つ目は, 雄しべは十分に発達しているが, 花粉が充実し ていない夕イプである. すなわち, 雄しべについては, 数は 6 本（Fig. 2D）で, 大きさや形は正常である（Fig. 2D, 2E). しかし, 花粉については, 形がつぶれていたり, 葯室の破裂 により放出される量が少ない (Fig. 2F). これをタイプ B と定 義した。
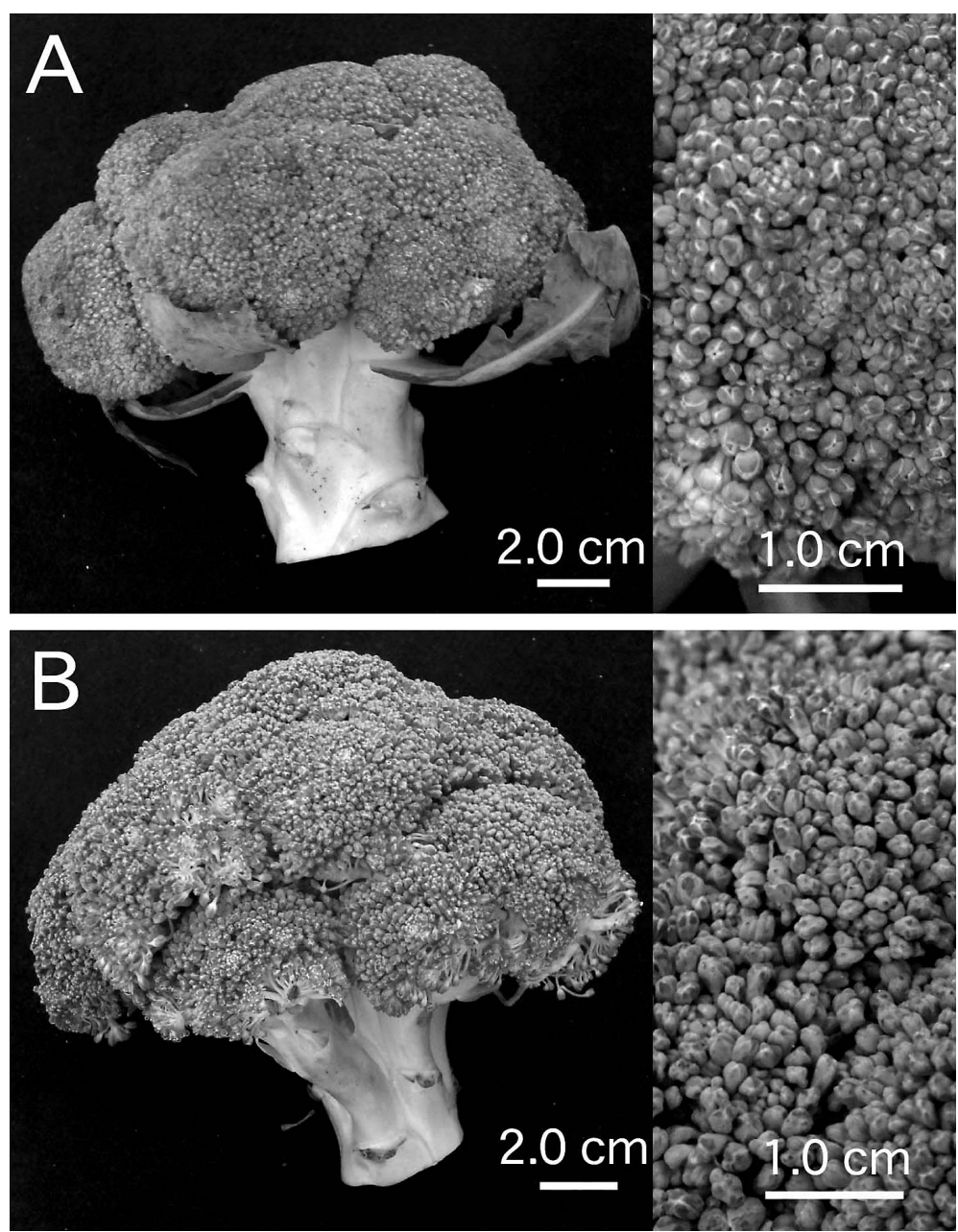

Fig. 1 Appearance of commercially grown broccoli. (A) Broccoli grown in Japan (Hokkaido); (B) broccoli grown in the USA. 

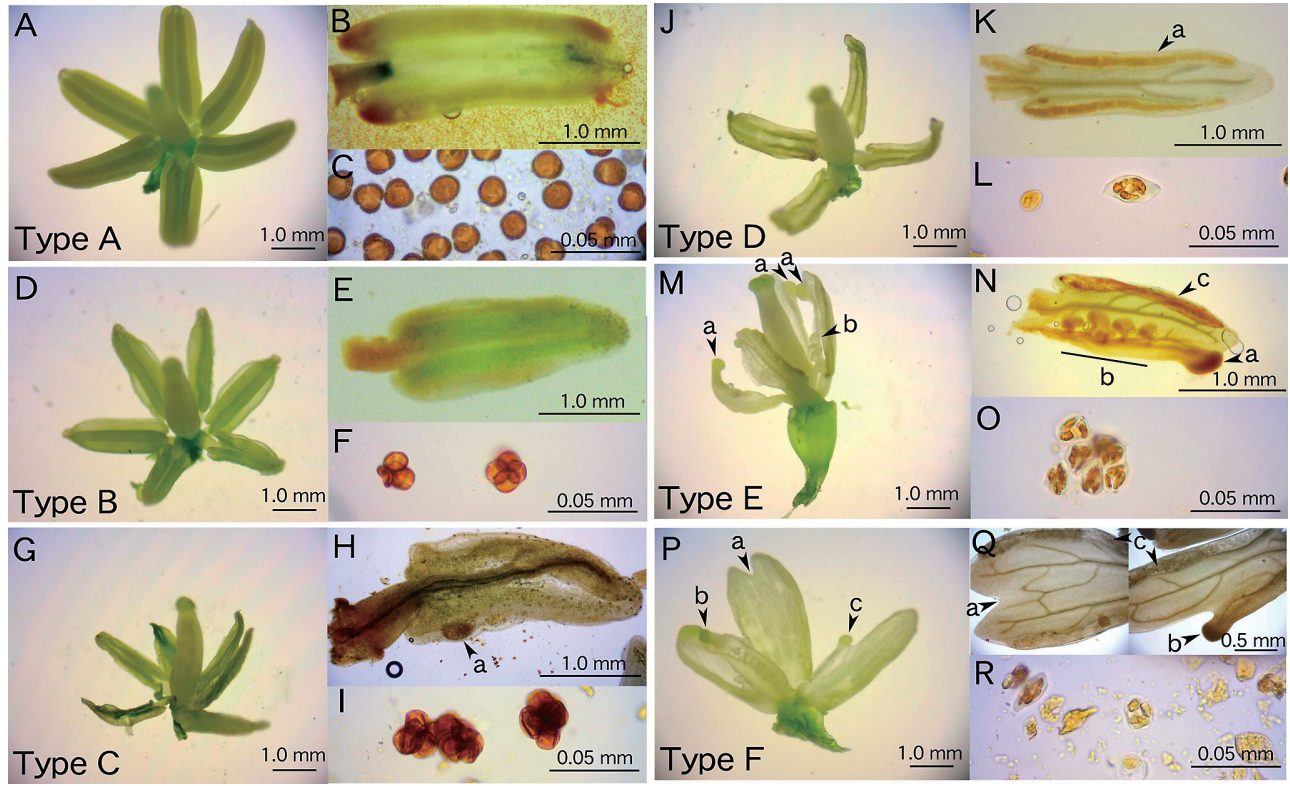

Fig. 2 Characteristics of sexual organs and pollen grains in the six flower bud types in broccoli commercially grown in Japan and the USA. (A) Stamens and pistil of type A flower bud. (B) Stamen of type A flower bud. (C) Pollen grains of type A flower buds. (D) Stamens and pistil of type B flower bud. (E) Stamen of type B flower bud. (F) Pollen grains of type B flower bud. (G) Stamens and pistil of type C flower bud. (H) Stamen of type C flower bud. a, Anther cell. (I) Pollen grains of type C flower buds. (J) Stamens and pistil of type D flower bud. (K) Stamen of type D flower bud. a, Anther cell. (L) Pollen grains of type D flower buds. (M) Stamens and pistil of type E flower bud. a, Stigma-like object; b, ovule-like object. (N) Stamen of type E flower bud. a, Stigma-like object; b, ovule-like object; c, anther cell. (O) Pollen grains of type E flower buds. (P) Stamens and pistil of type F flower buds. a, Conjugated stamens; b, pistil conjugated with stamen; c, stigma-like object. (Q) Stamen of type F flower bud. a, Conjugated stamens; b, stigma-like object; c, anther cell. (R) Pollen grains of type F flower buds.

3 つ目は, 雄しべは細く, 花粉が充実していない夕イプであ る. すなわち, 雄しべについては, 数は 6 本 (Fig. 2G) で, 形は細く弱々しい (Fig. 2G). 大きさや形が正常な雄しべに 混ざって, 葯室の形と大きさに異常が見られる雄しべ（Fig. 2Ha）も存在する. 花粉については, 形がつぶれていたり, 葯室の破裂により放出される量が少ない（Fig. 2I）。これを夕 イプ C と定義した.

4つ目は, 雄しべは薄く, 花粉が充実していない夕イプであ る. すなわち, 雄しべについては, 数は 6 本に満たないことが 多く (Fig. 2J では 4 本), 形は薄く平たい (Fig. 2J, 2K). 花粉については, 形がつぶれていたり, 葯室（Fig. 2Ka）の 破裂により放出される量が少ない (Fig. 2L)。これを夕イプ D と定義した。

5 つ目は, 雄しべは薄く一部雌性化し, 花粉が充実してい ない夕イプである. すなわち, 雄しべについては, 数は 6 本に 満たないことが多く (Fig. $2 \mathrm{M}$ では 4 本), 形は薄く平たい
(Fig. 2M, 2N). さらに, 雄しべの一部に柱頭様 (Fig. $2 \mathrm{Ma}, 2 \mathrm{Na}$ ) や胚珠様（Fig. $2 \mathrm{Mb}, 2 \mathrm{Nb}$ ) の構造物を有す る. 肧珠様の構造物は, 雄しべと雌しべの間に露出した状態 で存在する (Fig. 2Mb). 花粉については, 形がつぶれてい たり, 葯室（Fig. 2Nc）の破裂により放出される量が少ない (Fig. 2O).これをタイプEと定義した. タイプ D とタイプ E の 違いは雄しべの雌性化の有無である.

6つ目は, 雄しべは薄く一部雌性化し, かつ, 隣接する雄 しべや雌しべと融合し, 花粉が充実していない夕イプである. すなわち, 雄しべについては, 数は 6 本に満たないことが多く (Fig. 2P では 3 本), 形は薄く平たい (Fig. 2P, 2Q). さら に, 雄しべの一部に柱頭様（Fig. $2 \mathrm{Pc}, 2 \mathrm{Qb}$ ) や胚珠様の構 造物を有する. 肧珠様の構造物は, 雄しべと雌しべの間に露 出した状態で存在する. これに加えて, 隣接する雄しべとの 融合（Fig. 2Pa, 2Qa）や, 雌しべとの融合 (Fig. 2Pb) が 認められる. 花粉については, 形がつぶれていたり, 葯室 
（Fig. 2Qc）の破裂により放出される量が少ない（Fig. 2R）. これをタイプ $\mathrm{F}$ と定義した. タイプ $\mathrm{E}$ とタイプ $\mathrm{F}$ の違いは雄し べの融合の有無である.

以上のように, 生殖器官と花粉に基づき, 市販の日本産とア 䏚産ブロッコリーの蕾を A-F の 6 タイプに分類できた.

2. 日本産とアメリカ産ブロッコリーの蕾と個体におけるタイプ の解析

2013 年 4 月から 2014 年 3 月までに購入した日本産とアメリ カ産ブロッコリーにおける蕾のタイプの解析結果を Table 1に 示す. 日本産ブロッコリーでは解析した蕾 540 個 $(n=54)$ 全て（100％）が夕イプ A であった. アメリカ産ブロッコリーで は解析した蕾 910 個 $(n=91)$ のうち, タイプ A が 220 個 (24.1\%), タイプ Bが 132 個（14.5\%), タイプCが 68 個 (7.5\%), タイプ D が 167 個 (18.4\%), タイプEが 230 個 (25.3\%), タイプ F が 93 個（10.2\%）であった. 以上から， 解析した蕾に占める雄性不稔の蕾の割合は日本産ブロッコリ

Table 1 Types of flower buds of broccoli grown in Japan and the USA.

\begin{tabular}{ccccc}
\hline \hline & $\begin{array}{c}\text { Broccoli grown in } \\
\text { Japan }\end{array}$ & \multicolumn{2}{c}{$\begin{array}{c}\text { Broccoli grown in the } \\
\text { USA }\end{array}$} \\
Type & Number Percentage (\%) & Number & Percentage (\%) \\
\hline A & 540 & 100 & 220 & 24.1 \\
B & 0 & 0 & 132 & 14.5 \\
C & 0 & 0 & 68 & 7.5 \\
D & 0 & 0 & 167 & 18.4 \\
E & 0 & 0 & 230 & 25.3 \\
F & 0 & 0 & 93 & 10.2 \\
Total & 540 & 100 & 910 & 100 \\
\hline
\end{tabular}

一では 0 \%, アメリカ産ブロッコリーでは 75.9 \% であった. 2013 年 4 月から 2014 年 3 月までに購入した日本産および アメリカ産ブロッコリーに扔ける個体のタイプの解析結果を Table 2 に示す.「Type」のカラムには 1 個体につき 10 個の 蕾の夕イプの解析結果をもとに, 1 個体中に 1 つの夕イプの蕾 のみが存在する場合にはその夕イプを単独表記し, 複数の夕 イプの蕾が共存する場合には共存したタイプを並列表記し た. 前述のように, 日本産ブロッコリーでは解析した蕾 540 個 (n= 54) 全て $(100 \%)$ がタイプ A であったため, 54 個体 全てが夕イプ A の蕾のみが存在する個体である. 一方でアメ リカ産ブロッコリーにおいては, 1 個体中に 1 つのタイプの蕾の みが存在する個体と, 複数の夕イプの蕾が共存する個体が 存在した. すなわち, 解析した 91 個体のうち, タイプ Aの蕾 のみが存在する個体が 22 個体 $(24.1 \%)$, タイプ B の蕾の みが存在する個体が 7 個体 $(7.7 \%)$, タイプ C の蕾のみが 存在する個体が 4 個体 $(4.4 \%)$, タイプ D の蕾のみが存在 する個体が 2 個体 $(2.2 \%)$, タイプ E の蕾のみが存在する 個体が 1 個体 $(1.1 \%)$, タイプ B, C の蕾が共存する個体 が 9 個体 $(9.9 \%)$, タイプ D, Eの蕾が共存する個体が 12 個体 $(13.2 \%)$, タイプ D, F の蕾が共存する個体が 2 個体 $(2.2 \%)$, タイプ E, F の蕾が共存する個体が 6 個体 $(6.6$ \%), タイプ D, E, F の蕾が共存する個体が 26 個体 (28.6 \%)であった. タイプ Fの蕾は 93 個存在した（Table 1) が, タイプ F の蕾のみが存在する個体は見つからず（Table 2)，1個体中にタイプ D やタイプ E の蕾と共存することが明ら かになった. 1 個体に共存し得る蕾のタイプによって, タイプ $\mathrm{B}, \mathrm{C}$ の蕾が存在する個体（「BC 個体」と定義する）と, 夕 イプ D, E, F の蕾が存在する個体（「DEF 個体」と定義す

Table 2 Flower bud types in broccoli grown in Japan and the USA.

\begin{tabular}{|c|c|c|c|c|c|}
\hline \multirow[b]{2}{*}{ Type } & \multirow[b]{2}{*}{ Coexisting types } & \multicolumn{2}{|c|}{ Broccoli grown in Japan } & \multicolumn{2}{|c|}{ Broccoli grown in the USA } \\
\hline & & Number & Percentage (\%) & Number & Percentage (\%) \\
\hline A & & 54 & 100 & 22 & 24.1 \\
\hline $\mathrm{B}$ & & 0 & 0 & 7 & 7.7 \\
\hline $\mathrm{C}$ & $\mathrm{BC}$ individuals & 0 & 0 & \begin{tabular}{l|l}
4 & 20
\end{tabular} & \begin{tabular}{l|l|l|}
4.4 & 22.0
\end{tabular} \\
\hline $\mathrm{BC}$ & & 0 & 0 & 9 & 9.9 \\
\hline $\mathrm{D}$ & & 0 & 0 & 2 & 2.2 \\
\hline $\mathrm{E}$ & & 0 & 0 & 1 & 1.1 \\
\hline $\mathrm{F}$ & & 0 & 0 & 0 & 0 \\
\hline $\mathrm{DE}$ & DEF individuals & 0 & 0 & 1249 & $\begin{array}{lll}13.2 & 53.9\end{array}$ \\
\hline DF & & 0 & 0 & 2 & 2.2 \\
\hline $\mathrm{EF}$ & & 0 & 0 & 6 & 6.6 \\
\hline DEF & & 0 & 0 & 26 & 28.6 \\
\hline Total & & 54 & 100 & 91 & 100 \\
\hline
\end{tabular}



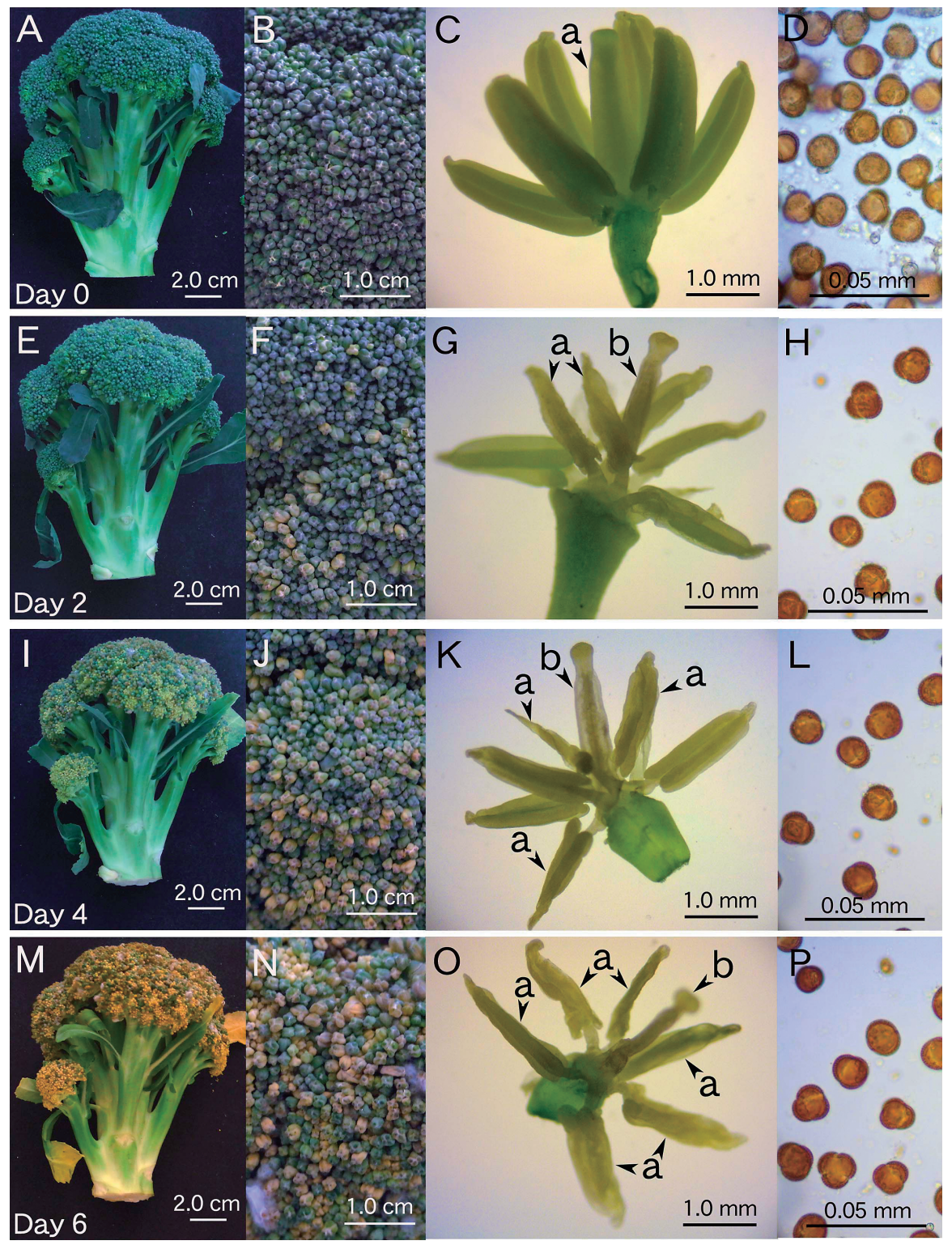

Fig. 3 Effect of $25{ }^{\circ} \mathrm{C}$ treatment for 6 days on the appearance, flower buds, sexual organs, and pollen grains of broccoli commercially grown in Japan. (A) Appearance at day 0. (B) Flower buds at day 0. (C) Stamens and pistil at day 0. a, Pistil. (D) Pollen grains at day 0. (E) Appearance after $25{ }^{\circ} \mathrm{C}$ treatment for 2 days. (F) Flower buds after $25{ }^{\circ} \mathrm{C}$ treatment for 2 days. (G) Stamens and pistil after $25{ }^{\circ} \mathrm{C}$ treatment for 2 days. a, Attenuated and decolorized stamens; b, decolorized pistil. (H) Pollen grains after 25 ${ }^{\circ} \mathrm{C}$ treatment for 2 days. (I) Appearance after $25{ }^{\circ} \mathrm{C}$ treatment for 4 days. (J) Flower buds after $25{ }^{\circ} \mathrm{C}$ treatment for 4 days. (K) Stamens and pistil after $25{ }^{\circ} \mathrm{C}$ treatment for 4 days. a, Attenuated and decolorized stamens; b, decolorized pistil. (L) Pollen grains after $25{ }^{\circ} \mathrm{C}$ treatment for 4 days. (M) Appearance after $25{ }^{\circ} \mathrm{C}$ treatment for 6 days. (N) Flower buds after $25{ }^{\circ} \mathrm{C}$ treatment for 6 days. (O) Stamens and pistil after $25{ }^{\circ} \mathrm{C}$ treatment for 6 days. a, Attenuated and decolorized stamens; b, attenuated pistil. (P) Pollen grains after $25{ }^{\circ} \mathrm{C}$ treatment for 6 days. 
る）に大別できた. 解析した 91 個体のアメリカ産ブロッコリー の中で, $\mathrm{BC}$ 個体は 20 個体 $(22.0 \%), \mathrm{DEF}$ 個体は 49 個体 (53.9\%) であった. 以上から, 解析した個体に占める雄性 不稔個体の割合は日本産ブロッコリーでは $0 \%$, アメリカ産ブ ロッコリーでは 75.9 \% であった. 特に, アメリカ産ブロッコリー では, 共存する表現型により雄性不稔個体を BC 個体と DEF 個体に大別できた.

\section{3. 収穫後の高温処理が生殖器官に及ぼす影響}

アメリカ産ブロッコリーの雄性不稔が収穫後の高温条件によ り誘導された可能性を検討するために, タイプ A の日本産ブロ ッコリーを用いて $25^{\circ} \mathrm{C}$ の温度処理を 6 日間行った. 処理 0 日 目では全体（Fig. 3A）および蕾（Fig. 3B）は濃い緑色であ った. 雄しべについては, 数は 6 本で, 大きさや形は正常で 濃い緑色であった（Fig. 3C). 雌しべについては, 数は 1 本 で, 大きさや形は正常で濃い緑色であった (Fig. 3Ca). 花粉 については, 形は正常で, 葯室の破裂により放出される量は 多かった (Fig. 3D). 処理 2 日目では全体（Fig. 3E）およ び蕾（Fig. 3F）の一部が退緑し茶色になった. 雄しべにつ いては, 6 本のうち 2 本が細く弱々しくなり, 退緑し茶色になっ た (Fig. 3Ga). 雌しべも退緑し茶色になった（Fig. 3Gb）. 花粉については, 形は正常で, 葯室の破裂により放出される 量は多かった (Fig. 3H). 処理 4 日目では全体（Fig. 3I）お よび蕾 (Fig. 3J) の半分以上が退緑し, 茶色や黄色になっ た. 雄しべについては, 6 本のうち 3 本が細く弱々しくなり, 退 緑し茶色になった (Fig. 3Ka)。雌しべの色はさらに薄くなった (Fig. 3Kb). 花粉については, 形は正常で, 葯室の破裂によ り放出される量は多かった（Fig. 3L). 処理 6 日目では全体 (Fig. 3M） および蕾（Fig. 3N）のほとんどの部分が退緑し 濃い黄色になった. 雄しべについては, 6 本全てが細く弱々し くなり，退緑し茶色になった (Fig. 3Oa). 雌しべは退緑し細く 弱々しくなった (Fig. 3Ob). 花粉については, 形は正常で, 葯室の破裂により放出される量は多かった（Fig. 3P). 以上 から, 収穫後の夕イプ A の日本産ブロッコリーに対して $25^{\circ} \mathrm{C}$ の温度処理を 6 日間行うと, 雌しべ, 雄しべの順に共に細く 弱々しくなり, 退緑し茶色になるが, 花粉の形や量には影響し ないことが示された. $25^{\circ} \mathrm{C}$ の温度処理により雄しべが細く弱々 しくなる点は夕イプ C の蕾の雄しべと酷似しているが, 雄しべ が退緑し茶色になる点, 雌しべも退緑し茶色になる点, 花粉 の形や量には影響しない点において, タイプ C の蕾の表現型 とは異なる. また, タイプ $\mathrm{B}, \mathrm{D}, \mathrm{E}, \mathrm{F}$ の蕾の表現型とも明らか に異なる. 従って, $\mathrm{BC}$ 個体と DEF 個体は収穫後の高温条 件により誘導されたものではないと考えられる。

4. 試験紙を用いたラテラルフローイムノクロマト法による除草 剂而性タンパク質の検出

アメリカ産ブロッコリーの雄性不稔が除草剂グルホシネート
耐性遺伝子またはグリホサート耐性遺伝子の組換えに伴い導 入された雄性不稳遺伝子に起因する可能性を, 日本産ブロッ コリー $(n=5)$ のタイプ A の蕾 5 個, $\mathrm{BC}$ 個体 $(n=5)$ の蕾 5 個, DEF 個体 $(n=5)$ の蕾 5 個を用いてラテラルフローイ ムノクロマト法により解析した. その結果, いずれも陰性であっ た (結果示さず).このことから, BC 個体と DEF 個体が除 草剤グルホシネート耐性遺伝子またはグリホサート耐性遺伝子 の組換えに伴い導入された雄性不稔遺伝子に起因する可能 性は低いと考えられる。

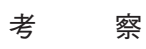

本研究では, 2013 年 4 月から 2014 年 3 月まで市販の日 本産とアメリカ産ブロッコリーにおいて雄性不稔の程度と割合 を解析した. その結果, 日本産ブロッコリーでは雄性不稔個体 は認められなかった（Table 2)。一方で, アメリカ産ブロッコリ 一では雄性不稔個体（BC 個体, DEF 個体）が $75.9 \%$ 存 在した (Table 2).これにより, 2012 年 8 月に著者の大学で 実施した学生実験においてアメリカ産ブロッコリーでは誰も花 粉を見つけられなかったことが偶然ではなかったことが裏付け られた. ただし, タイプ B-F と判定されたアメリカ産ブロッコリ 一の蕾においては, 花粉が全〈認められない蕾から葯室の破 裂により少量の花粉が放出される蕾まで, 蕾や個体によって 花粉量に程度差は認められた. 特に, 花粉が全く認められな い蕾を有する個体は初夏から夏に多く, 花粉を少量含む蕾を 有する個体は秋から冬に多い傾向にあった. また, アメリカ産 ブロッコリーにおいてタイプ A の蕾だけを含む個体は 10 月中 旬から下旬の一時期にのみ検出された. 日本に輸入されるア メリカ産ブロッコリーの産地や品種は一年を通じて変動する可 能性があるが, その詳細は不明である. 雄性不稔の原因に は一般的に生育環境と遺伝子がある. 以下, 各概略を説明 した上で, $\mathrm{BC}$ 個体と DEF 個体の原因を考察する.

雄性不稔の原因が生育環境にある場合とは, 温度, 水 分, 化学物質などの生育環境（環境ストレス）が, 生育遅 延, 花粉形成阻害, 受粉・受精障害などを引き起こし, 雄性 不稔を発生させる場合である. この場合, 雄性不稔は回避す べき障害である. 例えば, イネ (Oryza sativa L.) における遅 延型冷害, 障害型冷害, 旱害や, オオムギ (Hordeum vulgare $\mathrm{L}$.) における高温障害などである ${ }^{5-7)}$. オオムギの高 温による雄性不稔は植物ホルモンの一つであるオーキシン処 理により回復する ${ }^{8)}$. このように, 様々な環境ストレスにより植 物の生理状態が影響を受ける結果, 雄性不稳になる. む仮 に, $\mathrm{BC}$ 個体や $\mathrm{DEF}$ 個体が生育環境によって誘導されたの であれば, 日本産ブロッコリーにおいても BC 個体や DEF 個 体が一定の割合で出現するはずである. しかし，日本産ブロッ 
コリーからは BC 個体や DEF 個体は検出されなかった (Table 2). また, BC 個体や DEF 個体は収穫後の環境ス卜 レス（高温処理）でも誘導されなかった（Fig. 3). 従って， $\mathrm{BC}$ 個体や DEF 個体が生育環境によって誘導された可能性 は低いと考えられる.ただし,ブロッコリーに対して salicylhydroxamic acid (SHAM) や propyl gallate などのシ アン耐性呼吸の阻害剂を処理すると, BC 個体と同様の雄性 不稔が誘導される事例がある ${ }^{9)}$ ため, アメリカにおいて, 同 様の作用を有する農薬（化学物質）の散布によって BC 個 体が誘導された可能性は否定できない.

雄性不稔の原因が遺伝子にある場合, 雄性不稔は交配に よる育種に利用される. その理由は, 雄性不稔形質を導入し た種子親系統は, 杂隹種強勢を利用した一代雑種の育成にお いて交配の労力軽減に貢献するからである. また, 花粉が飛 散しないため, 近縁植物との交配を低減または防止でき, 生 態系の保護に役立つ. 雄性不稔系統の育成方法としては, まず, 前述のセイヨウナタネの事例のように, 雄性不稔遺伝子 を導入する遺伝子組換えによる方法がある. この場合, 導入 する遺伝子によって遺伝様式が決まる. また,「遺伝子組換 え農作物」に該当するため, 生物多様性への影響は「カル 夕へナ法」に, 食品としての安全性は「食品安全基本法」と 「食品衛生法」に, また, 飼料としての安全性は「飼料安全 法」と「食品安全基本法」に基づき, 科学的な評価を行 い, 問題がないものだけが栽培, 流通される（「遺伝子組換 え農作物」について, http://www.s.affrc.go.jp/docs/ anzenka/information/pdf/gmsakumotsu2013_11.pdf, 2014 年 5 月 28 日参照). 前述のように, ブロッコリーは, 2013 年 10 月末現在, 日本国内で販売や輸入が認められている遺 伝子組換え作物として, そもそも認可されていない. 念のた め, 本実験において専用の試験紙を用いてラテラルフローイム ノクロマト法により解析した結果, BC 個体と DEF 個体からは 除草剂グルホシネート耐性遺伝子またはグリホサート耐性遺伝 子由来のタンパク質は検出されなかった (結果示さず). 以 上から, BC 個体や DEF 個体が遺伝子組換えによって作出 された可能性は低いと考えられる.

雄性不稔の原因が遺伝子にある場合で, 従来から行われ ている雄性不稔系統の育成方法としては, 偶然発見した雄 性不稔個体を交配により系統化する方法や, 反復戻し交配に より近縁種の細胞質を導入した核細胞質雑種の中で雄性不 稔を示す個体を系統化する方法がある. 後者の例には, $B$. tournefortii の細胞質をもちB.napus またはB.juncea の核 をもつ核細胞質杂隹種 ${ }^{10,11)}$ や, B. r r p a の近縁野生種 Diplotaxis muralis の細胞質をもちB. rapaの核をもつ核細 胞質雑種 ${ }^{12-15)}$ がある. これらの核細胞質雑種では, BC 個 体と同様, 雄しべの発育不全や花粉量の減少が認められる.
また, コムギの近縁野生種 Aegilops crassa の細胞質をもちパ ンコムギ（Triticum aestivum L. cv. Norin 26）の核をもつ核 細胞質雑種 [(crassa)-N26] は, 穎花分化期の日長時間に 応じて雄しべが䧳性化する日長感応性細胞質雄性不稔 (Photoperiod-sensitive cytoplasmic male sterility: PCMS）を示すことが知られている ${ }^{16,17)}$. すなわち, この核細 胞質雑種 [(crassa)-N26] では, DEF 個体と同様, 「雄しべ の䧳性化」と「雄性不稔」が認められる. 解析したアメリカ 産ブロッコリーの中で BC 個体と DEF 個体はある一定の割合 (それぞれ $22.0 \%, 53.9 \%$ ）検出された（Table 2) ことか ら, その原因は偶然の生育環境ではなく, 遺伝子にあると考 えるのが妥当である. 以上から, BC 個体や DEF 個体は前 述の核細胞質雑種と同様の方法により選抜され育成された 雄性不稔系統の可能性が高いと考えられる.

前述のように交配により育成された雄性不稔系統では, 雄 性不稔形質は母性遺伝するため, 原因はミトコンドリアゲノム にあることが多い. 雄性不稔系統のミトコンドリアゲノムでは, 正常系統や細胞質提供親の核背景では転写されないが, 雄 性不稔系統の核背景では転写される Open Reading Frame (ORF) がもともと存在する場合や, 再編成により新たな ORF を生じる場合がある. これらの ORF は近傍のミトコンドリア遺 伝子と共転写される事例が多く, 共転写産物の有無や共転 写産物由来のタンパク質の有無が雄性不稔形質と相関性を 示すことから, これらの ORF が雄性不稔の原因と考えられて いる ${ }^{18-23)}$. もし仮に, BC 個体や DEF 個体が前述の核細胞 質雑種と同様の方法により選抜され育成された雄性不稔系 統なのであれば, BC 個体や DEF 個体において, 既存のミト コンドリア遺伝子と共転写される ORF が存在する可能性があ る.

植物の花の形態形成については, シロイヌナズナ (Arabidopsis thaliana L.) の突然変異体を用いた遺伝学的 解析により $\mathrm{ABC}$ モデルが提唱されている ${ }^{24-26)}$. このモデルで は, 花の外側から順に領域 1, 2, 3,4 定義し, 領域 1 では Aクラス遺伝子のみが働きがく片が, 領域 2 では A および $\mathrm{B}$ クラス遺伝子が働き花弁が, 領域 3 では B および C クラス遺 伝子が働き雄しべが, 領域 4 では C クラス遺伝子のみが働き 雌しべが形成されることを示している. また, Aクラス遺伝子と Cクラス遺伝子の発現場所は互いに拮抗する. 本研究にお いて, DEF 個体で認められた雄しべの雌性化はホメオティッ ク突然変異ととらえることができる. すなわち, DEF 個体では 領域 3 において B クラス遺伝子の働きが抑制されていると解 釈できる. 従って, DEF 個体においては, 既存のミトコンドリア 遺伝子と共転写される ORF の有無（原因）と, B クラス遺 伝子の働きの抑制 (結果) の因果関係の視点から解析する ことが今後望まれる. 
雄性不稔系統を利用した一代雑種の種子づくりは, アメリ カでは夕マネギ (Allium cepa L.) に始まり, トウモロコシやニ ンジン (Daucus carota subsp. sativus) など多くの野菜で実 用化されている. 日本でも雄性不稔系統を利用した一代雑種 の種子づくりが様々な野菜で実用化されている可能性がある が, スーパーの野菜売り場に並んでいる果菜類, 葉菜類, 茎 菜類, 根菜類では, 可食部が蕾や花ではないため, 一般の 消費者は雄性不稔系統を利用したものか否かを判別できな い. 一方で, ブロッコリー, カリフラワー, 菜の花などの花菜類 では, 可食部が蕾であるため, 実体顕微鏡や光学顕微鏡を 使用できる教育現場において, 蕾を解剖し雄しべや雌しべを 観察すれば雄性不稔か否かを判別できる（Fig. 2)，そのた め, アメリカ産と日本産ブロッコリーは生殖器官の比較により植 物の雄性不稔を理解するための身近な生物教材として教育 現場でも利用価值は高いと考えられる. 本実験では, 解析し た 54 個体の日本産ブロッコリーからは雄性不稔個体は検出 されなかった（Table 2) が, すでに日本でも細胞質雄性不 稔ブロッコリーが野菜として市販されているとの報告がある 27)。そこで実際に, 日本の大手種苗会社 2 社に問い合わせ た結果, 1 社からは, カ夕ログに掲載されている 11 品種のう ち 2 品種が細胞質雄性不稳ブロッコリーとの回答を頂き, 別 の 1 社からは, 個別に申し上げることはできないが, カ夕ログ に掲載されている品種の一部にはこの性質を利用して育成し ているものもあるとの回答を頂いた，そのため，調査地域を広 げれば, 日本産ブロッコリーからも雄性不稔個体が検出される 可能性が高いと考えられる. 市販のブロッコリーの雄性不稔 について, その分子メカニズムの解明と, 教育現場における 生物教材としての効率的な活用法の検討が今後の課題であ る.

\section{摘要}

2012 年 8 月に著者の大学で実施した学生実験で市販の ブロッコリーの花粉の観察を試みた際, 日本産ブロッコリーで は全員充実花粉を見つけられたが, アメリカ産ブロッコリーで は誰も花粉を見つけられなかった. これをきっかけに, 2013 年 4 月から 2014 年 3 月まで市販の日本産とアメリカ産ブロッコリ 一において雄性不稔の程度と割合を解析した. その結果, 雄 しべは十分に発達し, 花粉が充実している夕イプA, 雄しべ は十分に発達しているが, 花粉が充実していない夕イプ B, 雄しべは細く, 花粉が充実していない夕イプ C, 雄しべは薄 く, 花粉が充実していない夕イプ D, 雄しべは薄く一部雌性化 し, 花粉が充実していない夕イプ E, 雄しべは薄く一部雌性化 し, かつ, 隣接する雄しべや雌しべと融合し, 花粉が充実し ていない夕イプ Fの 6 タイプの蕾に分類できた. このうち, タイ
プ $\mathrm{B}, \mathrm{C}$ の蕾, タイプ $\mathrm{D}, \mathrm{E}, \mathrm{F}$ の蕾は, それぞれ 1 個体中に 共存したため, 雄性不稔個体を「BC 個体」と「DEF 個 体」に大別した. 日本産ブロッコリーでは季節によって産地は 変動したが, 全個体の蕾がタイプ A であった. すなわち, 雄 性不稔個体の割合は $0 \%$ であった. アメリカ産ブロッコリーで は夕イプ A の蕾だけが存在する個体は $24.1 \%, \mathrm{BC}$ 個体は $22.0 \%$, DEF 個体は $53.9 \%$ \%あった. すなわち, 雄性不稔 個体の割合は $75.9 \%$ であった. $25^{\circ} \mathrm{C} の$ 温度処理実験から, タイプ B-F の蕾は収穫後の高温条件により誘導されるもので はないことが示された. また, 専用の試験紙を用いたラテラル フローイムノクロマト法による解析から, タイプ B-F の蕾は除 草剂グルホシネート耐性遺伝子の組換えに伴い導入された雄 性不稔遺伝子に起因するものではないことが示唆された. 市 販のアメリカ産ブロッコリーに多く認められる雄性不稔個体は 交配による育種によって育成された可能性が高いと考えられ る.

\section{引用文献}

1）斎藤 隆. 蔬菜園芸の事典. 朝倉書店, 東京. 196258. 1991.

2）山㠃聖司. 教育現場で活用できる植物生理学実験一基 礎から応用まで一. ニシダ出版, 大阪. 6-8, 52-53. 2013.

3) 山㠃聖司,真鍋和人. ブロッコリーを利用した形態,組織, 細胞，および DNAを総合的に学習するための生物教 材の開発. 教育実践研究（福岡教育大学教育学部附 属教育実践総合センター紀要)。16:49-56. 2008.

4) 西尾 剛. IV. 植物の交配実験. 羽柴輝良・金浜耕 基編. 新農学実験マニュアル.ソフトサイエンス社,東京. 92. 2002.

5) Abiko M, Akibayashi K, Sakata T, Kimura M, Kihara M, Itoh K, Asamizu E, Sato S, Takahashi H, Higashitani A. High-temperature induction of male sterility during barley (Hordeum vulgare L.) anther development is mediated by transcriptional inhibition. Sex. Plant Reprod. 18: 91-100. 2005.

6) 日向康吉. 植物の育種学. 朝倉書店, 東京. 1-195. 1997.

7) Sakata T, Takahashi H, Nishiyama I, Higashitani A. Effects of high temperature on the development of pollen mother cells and microspores in barley Hordeum vulgare L. J. Plant Res. 113: 395-402. 2000.

8) Sakata T, Oshino T, Miura S, Tomabechi M, Tsunaga $\mathrm{Y}$, Higashitani $\mathrm{N}$, Miyazawa $\mathrm{Y}$, Takahashi $\mathrm{H}$, Watanabe M, Higashitani A. Auxins reverse plant male sterility caused by high temperatures. Proc. Natl. Acad. Sci. USA. 107: 8569-74. 2010.

9) Kishitani S, Konno N. Inhibitors of cyanideinsensitive respiratory pathway induce male sterility 
in broccoli (Brassica oleracea). Japan. J. Breed. 40: 217-222. 1990.

10) Liu Ji-H, Landgren M, Glimelius K. Transfer of the Brassica tournefortii cytoplasm to B. napus for the production of cytoplasmic male sterile B. napus. Physiol. Plant. 96: 123-129. 1996.

11) Pradhan AK, Mukhopadhyay A, Pental D. Identification of the putative cytoplasmic donor of a CMS system in Brassica juncea. Plant Breed. 106: 204-208. 1991.

12) Hinata K, Konno N. Studies on a male sterile strain having the Brassica campestris nucleus and the Diplotaxis muralis cytoplasm. 1 On the breeding procedure and some characteristics of the male sterile strain. Jpn. J. Breed. 29: 305-311. 1979.

13) Yamasaki S. Possibility of positive correlation between the delay of the meiosis stage of pollen development and the degree of male sterility among three alloplasmic lines of Brassica rapa containing Diprotaxis muralis cytoplasm. Environmental Control in Biology 52: 197-201. 2014.

14) Yamasaki S, Konno N, Kishitani S. An alteration in transcription patterns of mitochondrial genes in alloplasmic lines of Brassica rapa. Genes Genet. Syst. 73: 167-172. 1998.

15) Yamasaki S, Konno N, Kishitani S. Overexpression of mitochondrial genes is caused by interactions between the nucleus of Brassica rapa and the cytoplasm of Diplotaxis muralis in the leaves of alloplasmic lines of B. rapa. J. Plant Res. 117: 339344. 2004.

16) Murai K, Takumi S, Koga H, Ogihara Y. Pistillody, homeotic transformation of stamens into pistil-like structures, caused by nuclear-cytoplasm interaction in wheat. Plant J. 29: 169-181. 2002.

17) Murai K, Tsunewaki K. Photoperiod-sensitive cytoplasmic male sterility in wheat with Aegilops crassa cytoplasm. Euphytica 67: 41-48. 1993.
18) Bergman P, Edqvist J, Farbos I, Glimelius K. Male sterile tobacco displays abnormal mitochondrial atp1 transcript accumulation and reduced floral ATP/ADP ratio. Plant Mol. Biol. 42: 531-544. 2000.

19) Eckardt NA. Cytoplasmic male sterility and fertility restoration. Plant Cell 18: 515-517. 2006.

20) Kempken F, Pring DR. Male sterility in higher plants-fundamentals and applications. Prog. Bot. 60: 140-166. 1999.

21) Laver HK, Reynolds SJ, Moneger F, Leaver CJ. Mitochondrial genome organization and expression associated with cytoplasmic male sterility in sunflower (Helianthus annuus). Plant J. 1: 185-193. 1991.

22) Ogihara Y, Futami K, Tsuji K, Murai K. Alloplasmic wheats with Aegilops crassa cytoplasm which express photoperiod-sensitive homeotic transformations of anthers, show alterations in mitochondrial DNA structure and transcription. Mol. Gen. Genet. 255: 45-53. 1997.

23) Schnable PS, Wise RP. The molecular basis of cytoplasmic male sterility and fertility restoration. Trends Plant Sci. 3: 175-180. 1998.

24) Bowman JL, Smyth DR, Meyerowitz EM. Genetic interactions among floral homeotic genes of Arabidopsis. Development 112: 1-20. 1991.

25) Coen ES, Meyerowitz EM. The war of the whorls: genetic interactions controlling flower development. Nature 353: 31-37. 1991.

26) Meyerowitz EM, Bowman JL, Brockman LL, Drews GN, Jack T, Sieburth LE, Weigel D. A genetic and molecular model for flower development in Arabidopsis thaliana. Development Suppl. 1: 157-167. 1991.

27）鳥山欽哉. 細胞質雄性不稔 / 稔生回復に関わるイノベ ーション創出基礎的研究. 育種学研究. 15:63-67. 2013. 